able and do not obey the fiat of politicians, men of science, who understand these processes, are consulted by the politicians. By the application of modern scientific techniques such as the method of sampling, it is possible for the man of science to discover and understand the processes of society, and determine the needs of the people and the way in which they will react to certain new conditions. But at present these findings are only put into practice by a Government in so far as they do not conflict with the policy of that Government. By the neglect of this advice, however, the Government, while achieving immediate ends of its own, is running counter to the real development of society.

In the discussion which followed Prof. Bernal's paper, it was made clear that a Government based on science can only be put in power by an electorate informed of and appreciating the power of science and scientific method. The corollary to this is that every scientific worker of goodwill has to take on the role of agitator (used in the best English sense) and make public this revolutionary side of science. The Press and the B.B.C. should increase the portion of time devoted to science. Most important, however, must be the personal approach of scientific workers to local organizations such as trade unions, women's guilds and adult education movements. This activity is of the greatest urgency, and it will not do to wait until the end of the War is in sight.

\section{A Horticultural Centenary}

THE Gardeners' Chronicle entered upon its second century of publication with the issue of January 4. This war-time centennial birthday was marked only by an editorial of restrained dignity and a plate of the four founders with their first-born journal. Such attenuated celebration was necessitated by the large number of articles upon food production, which the Chronicle has fostered consistently since the outbreak of hostilities. Horticulture, with its roots in the activities of the first civilized man, had attained a considerable development by Roman times, but remained technically moribund until the beginning of last century. The static condition became, indeed, less profound in the Elizabethan epoch; but it was not until the nineteenth century that gardeners gave practical expression to their curiosity by searching the globe for new plants, by experimenting with the art of forcing, by erecting greenhouses, discovering new manures, crossing plants for new horticultural excellence, and keeping diseases and pests under control. 'The Gardeners' Chronicle was the journalistic crystallization of all this new development.

It was founded by a quartette of gentlemen, each of whom played his part in transporting horticulture from its shackles of feudal tradition into the noble combination of scientific art. Sir Joseph Paxton, Wentworth Dilke, John Bradbury and John Lindley united to initiate the journal, with Lindley as its first editor. The same group founded Punch and the Athenceum, also in 1841. John Lindley was a man of abundant energy, with a thorough knowledge of practical gardening, a profound knowledge of botany, and a talent for literary expression. His classical work "The Theory and Practice of Horticulture" collected the sum total of garden knowledge, and he began a line of practical but scientific editors whose title to write was a mandate from personal experience. Lindley was succeeded as editor by Maxwell T. Masters, famous for his work on plant teratology, and for his presidency of the Scientific Committee of the Royal Horticultural Society. Prof. (now Sir John) Farmer, carried on the editorial tradition for a few years and was succeeded by Sir Frederick Keeble, who has taught the present generation how "Science lends a Hand in the Garden", in an entertaining volume recently published. Sir Frederick is still scientific adviser, but the duties of editor have devolved in succession upon the late R. Hooper Pearson and Charles H. Curtis.

The Gardeners' Chronicle states simply and clearly the way to grow plants, but it has always attracted the scientific writer. Geo. Massee and M. C. Cooke, among the great mycologists of last century, frequently published in its pages, enriching the science of plant pathology from their experience of field mycology. More modern times have brought no less fundamental contributions, and in recent numbers readers will find a continuous series of articles on "The Garden in War-time", where the merits of various crops are considered from the point of view of food production. "Possible Sources of Organic Matter" are discussed by T. Laflin (Jan. 4 and 11); these include the residues from several industries, like bark scrapings, textile wastes and leather meal. Experiments on "Vernalization of Tomatoes" by D. W. Goodall and B. D. Bolas (Dec. 28) show promising results of increased fruit yield from chilling the seed, followed by incubation at $14^{\circ} \mathrm{C}$. before sowing. W. A. Millard contributes a photograph of a potato tuber attacked by the destructive forest parasite Armillaria mellea, the honey fungus. Thus the century-old tradition of a blend of science with practice is maintained, while from both men of science and gardeners come best wishes for the centuries that lie ahead.

\section{Journal of the Institution of Electrical Engineers}

Wrst the January issue the Journal of the Institution of Electrical Engineers appears in a new form. In a foreword to the new journal, Mr. J. R. Baird, the president, says that he feels sure that the change in form of the Journal has much greater justification than merely saving paper and preventing undue increase in the cost of publication. For some years past it has been increasingly felt that much of the material in the Journal has tended to become of a highly specialized character and therefore of interest only to limited sections of the membership. The new arrangement recognizes this difficulty by subdividing the Journal into three parts. Part $I$ is designed to include all matters likely to be of general interest to all members, including abstracts of all papers and "Institution Notes", through which members will be kept informed of the activities of the Institution. It is to be issued monthly and all members will receive 
it free. Parts II and III will include in full all specialized papers on "Power Engineering" and "Communication Engineering" respectively, thus giving recognition to the two main fields of electrical engineering activity. For these two parts members must apply specially and a small additional charge is to be made; Part II will appear in alternate months and Part III quarterly. Free advance copies of papers accepted for reading at meetings will still be available. Part III incorporates the Proceedings of the Wireless Section, and also includes papers on telegraphy and telephony; these are comparatively few and will probably be of interest to members of the Section. The new feature which has been introduced into Part I, of giving abstracts of all papers which are published in Parts II and III, will, it is felt, be of considerable value to all members.

\section{Earthquake in Cyprus}

ON January 20 at about 5.40 a.m. local time, an earthquake of considerable severity occurred, shaking the whole island of Cyprus for about half a minute. The epicentre of the earthquake was probably in the neighbourhood of the port of Famagusta, where forty-four houses are reported to have collapsed and other buildings damaged. The Cathedral of St. Nicholas was slightly damaged. Seven people are reported injured. At Nicosia some houses and one or two churches were cracked by the earthquake, though here no casualties are mentioned in reports so far received.

\section{The Night Sky in February}

DURING this month, the night shortens by nearly two hours in the latitude of London. The moon is full on February 12 and new on February 26. Lunar conjunctions with Jupiter and Saturn occur on February 3 at $19 \mathrm{~h}$. and $2 \mathrm{Ih}$. U.T. respectively. The moon is in conjunction with Mars on February 21 at $3 \mathrm{~h}$, the moon rising that morning at $3 \mathrm{~h}$. $47 \mathrm{~m}$. at Greenwich. Jupiter and Saturn still continue in close company, just within the southern limit of the constellation Aries, and they reach conjunction with one another on February 20 at $19 \mathrm{~h}$. On that day they come to the southern meridian at Greenwich at $16 \mathrm{~h}$. $30 \cdot 4 \mathrm{~m}$. Thereafter, Jupiter draws away eastwards from Saturn. The distant planet, Uranus (seen as a 6 th magnitude star but with a true disk $3 \frac{1}{2}$ in diameter), is just within the western border of Taurus, in a region south-preceding the Pleiades and devoid of stars as bright as the 6th magnitude. At the time of the planet's discovery in 1781 by Sir William Herschel, Uranus was in the neighbouring constellation of Gemini. By using a large range of powers (from 230 to 2000), Herschel was convinced from a telescopic examination alone that the object, called by him at first a 'comet', was definitely not one of the fixed stars. In mid-February at about 20h., Orion comes to the southern meridian. Light changes of the variable star Algol ( $\beta$ Persei), may be observed about $1 \frac{1}{2}$ hours before and after the following times : February 9 d. $4 \cdot 9 \mathrm{~h} .: 12 \mathrm{~d} .1 \cdot 7 \mathrm{~h} .: 14 \mathrm{~d} .22 \cdot 5 \mathrm{~h}$. and 17d. 19.4h. U.T. (add 1 h. to reckon in Summer Time).

\section{Announcements}

THE Council of the Geological Society has made the following awards: Wollaston Medal to Dr. A. L. Day, of the Geophysical Laboratory, Washington, D.C.; Murchison Medal to Dr. Murray Macgregor, of H.M. Geological Survey (Scotland); Lyell Medal to Mr. Ernest Sheppard Pinfold; Bigsby Medal to Dr. C. J. Stubblefield, of H.M. Geological Survey; Wollaston Fund to Dr. K. P. Oakley, of the British Museum (Natural History); Murchison Fund to Dr. John Weir, of the University of Glasgow ; a moiety of the Lyell Fund to Mr. W. Eltringham; another moiety of the Lyell Fund to Dr. F. S. Wallis, of the Bristol Museum and Art Gallery.

The Buchan Prize for 1941 of the Royal Meteorological Society has been awarded to Mr. H. L. Wright for papers contributed to the Quarterly Journal of the Society during 1935 -39.

THE Chadwick Trustees recently offered two prizes of $£ 100$ and $£ 50$ for essays on the construction and management of air raid shelters, with special reference to ventilation, heating, sanitation and the provision. of sleeping accommodation. The prizes have been awarded as follows: $£ 100$ to Mr. Phillip O. Reece and Dr. S. L. Wright, of Wembley, Middlesex ; $£ 50$ to Mr. Jocelyn F. Adburgham, of Victoria Street, Westminster, S.W.1.

A Neurologicar Section has recently been added to the Caroline Medical Institute in Stockholm, the principal medical school of Sweden, under the direction of Prof. Ragnan Granit, an international authority on electro-physiology.

THE following appointments have recently been made in the Colonial Service: G. L. Bannister, veterinary officer, Tanganyika Territory; J. D. Birkett, veterinary officer, Nigeria; R. W. E. Lewis, veterinary officer, Kenya; I. B. Pullon, veterinary officer, Tanganyika Territory; D. S. Davies (senior agricultural officer, Uganda), deputy director of agriculture, Palestine; H. R. Hosking (botanist), senior botanist, Uganda; J. D. Jameson (agricultural officer), botanist, Uganda.

Mr. T. H. HAwkINs, education officer of the Educational Advisory Board of the British Social Hygiene Council, is resigning his position, in any event for the duration of the War and possibly permanently. The War Emergency Committee of the Educational Advisory Board has been actively promoting both the School Leavers' Courses and the lectures to young people. The education officer is responsible for the administrative work relating to the Educational Advisory Board, the printing and issue of Biology under the direction of the editor, conferences and courses of lectures to teachers on the teaching of biology relating to human problems, and short courses of instructional lectures on the place of sex in life to the 16-23 age group. Applications are invited for this post. Further information can be obtained from the Acting Secretary, the Educational Advisory Board, Tavistock House South, Tavistock Square, W.C.1. 